\title{
Stereotyping Indigeneity: the Case of Native American
}

\author{
Svitlana Lyubymova \\ National Polytechnic University, Odessa, Ukraine. Orchid ID oooo-ooo1-7102-37ox. \\ Email: elurus20o6@gmail.com \\ First published July 19, 2019
}

\begin{abstract}
Raising awareness of indigeneity comes forward with strengthening of cultural globalization. The lack of relevant knowledge of indigenous cultures results in persistent stereotyping. Regarded the representation of an ethnic group, a stereotype is based on implicit assumptions and behavioral implications that are reflected in evaluative characteristics. Stereotypes are spread by mainstream culture through popular media and cinema. This work attempts to profile the stereotype of Indigenous American created by mainstream American culture on the results of qualitative analysis of media discourse. Treated as uncivilized, Native Americans are portrayed as unbending and cruel warriors or as wise and helpful friends of White. America's attitude to Indians is changing from banishing to extolling. The deconstruction of stereotypes in humanitarian paradigm is the matter of acknowledgment of cultural uniqueness and establishment of social equality.
\end{abstract}

Keywords: stereotype, Indigenous American, mainstream culture, media discourse.

\section{Introduction}

Raising awareness of indigeneity has come forward with strengthening of globalization processes. The term "indigenous peoples" refers to "disadvantaged descendants of the peoples that inhabited a territory prior to colonization or the formation of the existing state" (Sarivaara et al., 2013). According to the report of International Work Group for Indigenous Affairs, indigenous peoples live in every region of the world. The world's total indigenous population varies from 200 million to 370 million, 1.5 million of which live in North America (Sarivaara et al., 2013).

The word indigenous, originated from Latin root indi-gena in the meaning of "natural, native, local". It occurred in English in the 17th century, the period of establishing the Pilgrims colony, the Salem Witchcraft trials, and Benjamin Franklin's republicanism in America. In other languages of people who established the colonies on discovered territories of America, the meaning of "native, original inhabitant of a particular place" exists in French (indigénat), in Portuguese and Spanish (indígena). In German the word of the same origin, Indigenatsrecht, means "granted civic rights". Namely, the right of indigenous peoples to preserve their social and political institutions, and their cultural authenticity is the issue of global concern. The assimilation process with mainstream cultures threatens loss of indigenous cultural identity. And on the contrary, ethnocentrism might lead to false assumptions about others' ways, especially when our knowledge is based on our own limited experience.

(c) AesthetixMS 2019. This Open Access article is published under a Creative Commons Attribution Non-Commercial 4.0 International License (http://creativecommons.org/licenses/by-nc/4.o/), which permits non-commercial re-use, distribution, and reproduction in any medium, provided the original work is properly cited. For citation use the DOI. For commercial re-use, please contact editor@rupkatha.com. 
Our knowledge of the far from our ancestry cultures are based mostly on sources of popular literature and films. Largely the knowledge we get comes with great risk that these cultures are misrepresented in stereotypical and inaccurate manner. This is evident in representations of indigenous peoples by dominant popular cultures. The purpose of this work is to profile the stereotype of American Indians, i.e. to construct basic variants of representations in popular culture and clarify whether there is conformity of the stereotype to reality.

\section{Defining a Stereotype from Different Perspectives}

There are three main lines of investigation of stereotypes and stereotyping. The first focuses on cognitive processes involved in categorization and abstraction of social knowledge. In this view, stereotype is a result of basic human cognitive activity connected with the mental operation of detecting similarities and distinctions with already established categories. Stereotypes represent simplified and reduced information about social groups (Quasthoff, 1978; Putnam, 1988; Ashmore, R. D., Del Boca F.K., 2015).The human mind works "with the aid of categories...Orderly living depends on it" (Allport, 1954).

Indispensable to human mental activity, stereotypes are an integral part of natural language. They are maintained and changed through language and communication. Representing the image of a group in its verbal form, a stereotype forms the center of semantic and cognitive associations (H. Tajfel, 1981; F. Coulmas, 1981; Teun A. van Dijk, 1984).

The second line of investigation points out affective attitudinal component of stereotyping. Category distinctions influence perception of and behavior toward category members, individually and collectively (Brewer, 2005). Ambivalent character of a stereotype reflects duality of appraisal. This essential feature of stereotypes is described as "a split" between "good" and "bad".

The third line of investigation is aimed to investigate a social aspect of stereotyping (D. T. Campbell, 1956; H.Tajfel, 1969; R. Taguiri, 1969; J. H. Turner \& S. T. Fiske, 1998). The regulative function of stereotypes is an inalienable part of ethnic group operation. Viewed from this perspective, a stereotype is the identification pattern that assumes membership with a certain group. People's individual characteristics and their group memberships play a significant role in shaping attitudes, values, beliefs, evaluative, and behavioral implications.

These approaches lay the groundwork for my study. I regard a stereotype as representation of an ethnic group, which is based on implicit assumptions and behavioral implications. Stereotypes are reflected in evaluative characteristics that manifest in language. Emotionally perceived, stereotypes are represented by stable set of external and ethical characteristics. Thus, a profile of a stereotype comprises a set of descriptors, depicting visual and ethical characteristics. Visual characteristics comprise physical (face features, figure) and clothing peculiarities. Ethical characteristics include moral qualities and behavioral distinctive features.

Stereotypic descriptors manifest in different forms of judgments about certain attributed or denied features of stereotyped objects (U.Quasthoff, 1978; Bartmiński, 1997). The common feature of all stereotypical judgments is covert universal generalization, i.e. a certain property is ascribed to all, rather than to just some exemplars of a category (Bartmiński, 2016).

Circulating in the society as shared background knowledge, stereotypes present certain unquestionable beliefs. They are cognitive presuppositions, which are stored in collective memory in forms of scripts and frames (Stalnaker, 1974; Kiefer, 1978). Presuppositions are not necessarily 
based on patterns of life experience, either they are not individually asserted and justified. They are ratified by epistemic criteria of a community and thus considered true (van Dijk, 1998: 19). These implicit assumptions are spread by mainstream culture through popular media and cinema.

\section{What's in the Name?}

The famous phrase from Shakespeare's "Romeo and Juliet" conveys the idea that a name correlates not with intrinsic qualities of people, but with conventional opinions of them. The name rather manifests the label that the society uses in accordance with commonly accepted ideas about individuals or groups.

Indigenous people of the United States are used to be named by exonyms, which are names given to a place or group of people by aliens. The term Indian was introduced by first colonists irrespective of the natives' affiliation with one of 300 distinct tribal languages. The legend tells that Christopher Columbus referred to the indigenous people as Indians mistakenly taken the Caribbean for the Indian Ocean. White settlers picked up the name. The terms currently in popular rotation are Native American and American Indian. They refer to all culturally diverse North America's tribes unitarily perceived as a homogeneous people. Native American replaced the use of American Indian in the 196os, the trend that showed the political correctness as mode to treat troublesome questions.

European colonists imposed a collective identity on the Indians by the very name. Even the names of Indian tribes as Navajo, Sioux, and others, were introduced by European settlers. The word Navajo is a Spanish adaptation of the Tewa Pueblo word navahu'u, meaning "farm fields in the valley". Early Spanish chroniclers referred to the Navajo as "Apaches de Nabajó" that means "Apaches who farm in the valley", later shortened to Navajo (Crow Canyon Archeological Center, 2019).

The name Sioux comes from Nadowe $\mathrm{Su}$, which is the language of the Algonquin people, with about 3000 speakers, and has the meaning "Little Rattle". It is supposed to come from the rattling sound a snake makes before it bites. French traders changed the spelling from Su to Sioux and dropped Nadowe. This is how the great Oceti Sakowin became commonly known as Sioux. The Sioux language has three dialects, which developed because the Sioux were spread out over the vast plains region of North America (Acta Lacota Museum, 2019). Many Natives identify themselves by tribe names.

What it meant to be an Indian was defined by European settlers and imposed upon Native Americans. Classified as Mongoloid, or Oriental/Amerindian race, Indigenous Americans are named in popular culture as redskins or redface. These pejorative terms are conditioned by simplified classification of race based on exterior conformity. The "awareness of "national" differences outweighed anything approaching a modern tendency to identify a particular skincolor or physiognomy with a "race" (Hudson, 1996: 250).

Conveying the colonial past of the United States the term Indigenous American associates native population with inferior to White barbarians. Close to above mentioned term is savage. As early as the 16th century De Acosta distinguished indigenous Americans as "barbarous" peoples who wander "like savage beasts" (Hudson, 1996: 249-250). The ingrained tradition to treat Indigenous American as primitive and uncivilized as it was in the time of first settlers, is still persists in stereotyping native population of North America. In fact, there is no term appropriate in all instances when referring to the indigenous peoples of America, as it alienates these people from the rest of American population. "Attributing a stigmatizing name to an individual or group can affect their own acceptance of certain qualities and lead to them acting in accordance with 
those labels" (Bartminsky, 2016: 119). This is proved by the fact of spreading criminal organizations on Indian territories. Treated as uncivilized, Native Americans are depicted in popular culture as unbending and cruel warriors, or as wise and helpful friends of White. Thus, we see America's attitude to Indians is changing from banishing to extolling.

\section{Ethnocentrism of Stereotyping Indigeneity}

In 1886, Theodore Roosevelt, the US President from 1901 till 1909, said: "I don't go so far as to think that the only good Indian is the dead Indian, but I believe nine out of every ten are, and I shouldn't like to inquire too closely into the case of the tenth. The most vicious cowboy has more moral principle than the average Indian" (Hautman, 1975). Reflecting racist attitude to Indigenous American, the words of American President show dominating till the 2oth century ideological principle of white supremacy in the USA.

The First Nations Development Institute, a national organization dedicated to Native economic development, conducted the research on dominant narratives about indigenous people in the United States. The research team surveyed 28 focus groups in 11 states and 13,306 people online, analyzing 4,9 million social media posts. The study showed that the information about Native Americans is "based and guided by misperceptions, assumptions and stereotypes". Respondents, especially those living near Indian Country, listed negative associations with reservations such as "They drink too much and get in fights" and "Alcohol abuse. Drug abuse. Child abuse. Gambling addictions." (Nagle, July, 2018).

Though celebrating rich cultural heritage of Indigenous American, white Americans altogether deny natives' otherness. The example of such attitude is the 2018th Netflix series "Unbreakable Kimmy Schmidt" that shows a contemporary urban Native American woman from New York City, who became "extremely white". The show teaches its vastly audience that a civilized Indigenous American who breaks all the stereotypes is a really White (Nagle, June, 2018).

The mainstream American culture romanticizes Native people. This attitude is traced back to the accounts of writers and explorers from previous centuries. Many people, not only in the USA, were acknowledged with life of American Indians from romantic and sympathetic books of W. Irving and F. Cooper. W. Irving (1783-1859) dedicated "A Tour on the Prairies" (1835), "Astoria” (1836), "The Adventures of Captain Bonneville" (1837) to honorific portrayal of Indians that fought against European invaders. In "The Indian in American Literature", A. Keiser states that "the writer who more than anyone else impressed his conception of the Indian upon America and the world at large is James Fenimore Cooper (1789-1851), in eleven of whose books the red man plays a prominent part" (Keiser, 1970: 101). In five novels of "Leatherstocking Tales" (1823-1841) and other of his books, the writer shows Indians' benevolent help to defend the English settlers against hostile attacks by other native tribes and the French. A. Keiser remarks that in characters, such as Uncas, Hard-Heart, and Chingachgook, F. Cooper "heightened the noble qualities within the bounds permissible in romances" (Keiser, 1970: 112). Fascinating stories of F. Copper that romanticize noble Indian warriors were first filmed as western serial "Leatherstocking" in 1924. It was followed by other TV and big-screen movies based on Cooper's books.

The life of Indian tribes as well as their relationship with European settlers have drawn attention of filmmakers since the silent films' era. Already in the first films, it is evident that the image of Indigenous American falls into two definite parts: "good" and "bad", i.e. the intrinsic feature of stereotypes. In "Heart of an Indian" (1912) Thomas H. Ince showed sensitivity and empathy of Indians, while in "The Battle of Elderbrush Gulch" (1914) D.W. Griffith's depicted the 
Indians as vicious savages. Love to a savage woman was accepted in the society with much disapproval and hostility, as it is shown in "The Bronze Bride" (1917). "The Vanishing American" (1925) and "Broken Arrow" (1950) present a "noble savage" stereotype. In these films, American Indians were depicted as half-clothed savages, screaming war cries. Hollywood exported this image of American Indians to the entire world.

A Native American media scholar from University of Massachusetts, Virginia McLaurin, assumes that there is no changes in stereotyping Indigenous people, particularly in television. McLaurin analyzed approximately 60 popular TV shows, films, and books from the early 1990 s to 2011 with aim to find out what impression the average non-Native consumer would have of today's Native Americans from the media they grew up with. She found that the stereotype of Indigenous American persists.

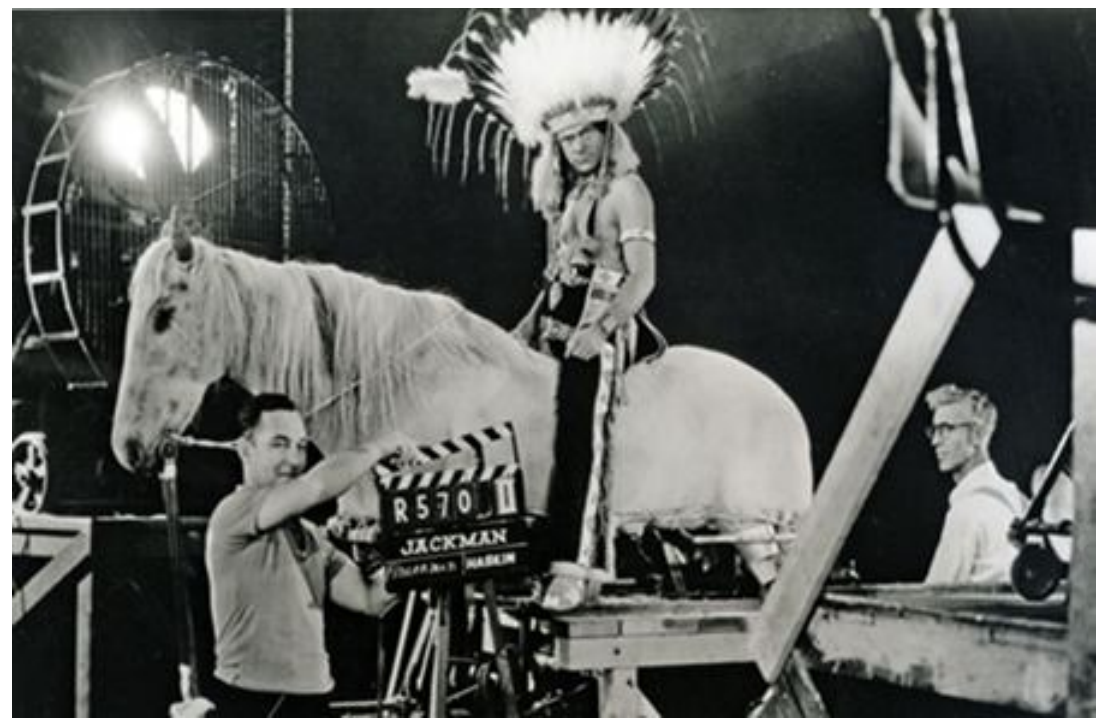

Figure 1: Hollywood filming Native American story

The negatively portrayed Indigenous characters were generally out of touch with their culture; they also often received benefits, operated casinos, were untrustworthy, and were frequently suggested to be "fake" Native Americans, especially in the eastern half of the country, where lineage is more likely to be "mixed". Meanwhile, the more positively portrayed Indigenous characters were poor, living on reservations, honest, culturally knowledgeable, and often involved in supernatural occurrences. Most often in westerns and historical dramas, especially prior to the 1960 , Indigenous characters were portrayed as "good", if they consistently and successfully assist the colonists. McLaurin continuous: "The "bad" Indigenous characters were depicted as secretive or unwilling to assist Euro-American characters, while the "good" ones led Euro-American protagonists to gold, free land, help for their injuries, spiritual enlightenment, or anything else they needed or wanted" (McLaurin, 2019). "Noble savage" is always portrayed like that in films: such was Squanto in "Squanto: A Warrior's Tale" (1994) and Pocahontas of Disney classic animated film (1995). They give food and assistance to European colonists, who appropriate land of Indigenous American, but celebrated their disinterested help by Thanksgiving Day. White settlers of America seek either wisdom or guidance of indigenous people (like in the film "Dances with Wolves", 1990), or treasures belonging to Indigenous American (as in the film "Tillamook's Gold", 2006). Utilitarian principle of being useful for European settlers, imposed on EuroAmerican by mainstream culture determines the attitude to Indigenous American and evaluation 
of them. Thus, two opposite frames "vicious savage" and "noble savage" represent a stereotype of Indigenous American in popular culture (Table 1).

Table 1.Vicious Savage vs Noble Savage

\begin{tabular}{|c|c|}
\hline Vicious Savage & Noble Savage \\
\hline $\begin{array}{c}\text { secretive or unwilling to assist European } \\
\text { settlers }\end{array}$ & $\begin{array}{c}\text { helpful for European settlers in search of } \\
\text { gold and free land }\end{array}$ \\
\hline scalping European settlers & treating injuries of European settlers \\
\hline shamanism & spiritual enlightenment \\
\hline tomahawks, naked bodies, war paint & dressed in buckskin and feathers \\
\hline cruel & innocent \\
\hline primitive & ine \\
\hline
\end{tabular}

The Hollywood image of the Native American is a sexually attractive, both male and female. Either brave warrior with well-shaped body or extremely beautiful, innocent "Indian Princess" evokes audience's liking. This intensive sexuality is caused by "the presumed lack of mental prowess" of the Native American who is depicted "more creature than human, more bestial than celestial" (Kilpatrick, 1999). The degree of objectivity in shaping the images of Indigenous American in popular culture is disputable question.

\section{Subjectivity in Representing Indigeneity}

A stereotype of Indigenous American implies that natives are impoverished, completely immersed in Indigenous culture, and helpful to outsiders. "What exists or what is real is not always agreed upon. What happens can be described in different ways, in ways that invoke not only different evaluations, but also different ontological perspectives" (Chilton, 2004: 49). It is the case of American Indigeneity that can be described as a persistent stereotype known all over the world due to literary and cinematographic works. Stereotypes are shaped mainly by assumptions and presuppositions of what exists in reality, rather than clear perception of reality. Reinforcement of a stereotype is conditioned by absence of real-life information, therefore one of the primary goals of American Indian Movement, which started in the 1970s, "was to take away from so-called white experts the responsibility for describing contemporary Indian culture” (Alcalay, 1998).

Not everyone who has enjoyed reading "The Last of the Mohicans" knows that the Mohicans do indeed still exist, as the Stockbridge-Munsee Community (McLaurin, 2019). Today, as a result of the Indian Reorganization Act, about one-third of the total Indian population lives off reservations in urban areas (Acta Lacota Museum, 2019).

American Indian Movement awakened indigenous peoples' self-consciousness. Free from governmental control national Indian organizations have spread throughout the Indian country. A number of important for Indigenous American acts were introduced, such as Federal protection 
for offenses against Indians, national Indian voting with local options. Passed by Congress in 1990, the Native American Graves Protection and Repatriation Act mandates to consult with tribal communities when managing their material heritage (Montgomery, 2017). The act sets an important precedent for how to interact respectfully with tribal communities, whose rights have been systematically abused and ignored for centuries.

Organizations and artistic venues, such as the Red Path Theater Company, the American Indian Film Institute in San Francisco, Red Earth Film Festival, provide networking opportunities and serve as excellent support for indigenous artists. Through active involvement in the visual and performing arts, American Indians are continuing their cultures and improving American Indian images that are viewed by diverse cultures around the world (Alcalay, 1998). American Indians are seizing control of their own narratives in culture instead of passively waiting for American public organizations to change racial attitudes to them.

As reported by Native Youth Magazine, Native Americans are in charge of some of the largest resource development companies, restaurant chains, casinos, and capital investment firms, financing companies all over the country. An example of Native American success is David Anderson. Raised on traditional native values, Anderson studied at Harvard and made a big name as the head of the "Famous Dave's" chain of restaurants, the major restaurant chain that can be found throughout the United States.

Native Americans have also become very influential in the financial world. A very successful example of native ingenuity applied to finances is Ho-Chunk Incorporated. Started in 1994 with a mission to advance the economic interests of the Winnebago Indian Reservation in Nebraska, this company has taken a community with over $60 \%$ unemployment and turned it into one of the most financially stable communities in Native American society. There are a number of successful businesses run by native individuals and communities. Native American business people are statistically the most likely to contribute extensively to the communities they have come from (Native Youth Magazine, 2019).

In 2019, the first two Native American women were elected to Congress: Democratic Representative Deb Haaland of New Mexico and Sharice Davids of Kansas. In the interview to CNN, Deb Haaland said: "I'm proud to have encouraged and contributed to several Native women this past cycle who won their state House seats. I believe that Native women are seeing positive role models in the wins that happened this year. I will keep supporting them" (Kelly, 2019).

The iconic image of painted savage in fringed and feathered clothes is merely Hollywood creation. Inherent to indigenous look, feathered headdress was a kind of regalia not meant for casual or every-day wear. Feathers are sacred for many tribes (Young, 2015). Instead of feathers and leathers, today's Indian renegades wear baseball caps and baggy pants (Ahtnon, 2018: 57).

The visual image of American Indian is challenged by Indigenous artists that strive to redefine and reclaim Native art. Young Indigenous designers are using their collections to spotlight cultural activism. "The biggest misconception about indigenous design is that it's all the same," said designer Bethany Yellowtail for the "Vogue" (Allaire, 2018). Sameness and typicality in perception of indigenous culture uphold the stereotypes. One of the prominent indigenous designers, Bethany Yellowtail, is studied design at the Los Angeles Fashion Institute. She launched her own brand of traditional wing dresses and skirts.

Law prohibits misrepresentation in marketing of indigenous arts and crafts' products within the United States. One of this country's largest Native American tribes, the Navajo Nation, accused "Urban Outfitters" of cultural appropriation, as the clothing company used the Navajo 
name and symbols without permission (NPR, 2012). In September 2016, the two parties signed a settlement agreeing to collaborate on the production and marketing of Navajo products. The Navajos have already endorsed products. For example, Mazda got the permission from the Navajo Nation to use the word Navajo. For the past 25 years, the Navajo Nation has passed a number of laws trying to protect their authenticity of culture (Lubitz, 2016).

In 2016, the project "Reclaiming Native Truth", which was designed to increase understanding of Native Americans in the United States, has enabled people to explore unprecedented areas of research to reveal a new understanding of public perceptions and dominant narratives that affect Native peoples within American society. However, a new narrative, in which a new stereotype of a smothered and over-protected indigeneity is creating, can be marred by native gangs' activities. Despite noticeable changes in positive identity development, there is the growing threat of Native organized crime. Native American gangs are relatively new phenomenon that appeared in 1980s-1990s, when city gangs introduced themselves to Indian Country. They are notoriously active in Minnesota, Wisconsin, and South Dakota. There are 5,000 young men from the Oglala Sioux tribe involved with at least 39 gangs on the Pine Ridge Indian Reservation. The gangs are being blamed for an increase in vandalism, theft, violence and fear that is altering the texture of life here and in other parts of American Indian territory. The Navajo Nation in Arizona has identified 225 gang units, up from 75 in 1997 (Eckholm, 2009). On the Navajo Nation Reservation 60-70 active gangs have been identified with approximately 1,500 to 2,500 individuals claiming some level of gang affiliation (Grant, 2013).

In early 1990s, gangs of Native American neighborhoods primarily existed for protection, but in 2013, the gangs' members became involved in drug trafficking, weapon-sales, assault, murder, and racketeering. Native gangs' threat to positive identity of Native American is the outcome of social dysfunction and natural reaction to hostile environment, cultural alienation, the loss of their language and land, the destruction of family and social structures. "It's a story about how historical trauma, federal policy, and tribal pride have created a new Indian problem: organized crime". (Ahtnon, 2018: 53). Federal government assists Indian Country to curb gangs' activity. In 2009, President Obama provided some reservations with additional resources to reduce crime. However, the continuation of these efforts are dependable on federal budgeting. Many native communities are trying to address gangs' growing problems by adopting conventional prevention programs in schools and communities. Programs preventing drug abuse and resistance to education are being introduced. Other programs target to strengthen families and recreational activities (Freng, 2014: 16-18). While the lack of cultural connectivity is one of the many contributing factors to gang involvement in Indian Country, on-going efforts to revitalize traditional culture have resulted in positive outcomes. For example, while statistics suggest that less than $30 \%$ of all Native Americans in the U.S. speak their tribal language, the development of language immersion schools in Indian Country is changing, resulting in higher educational achievement. Instilling pride in culture strengthens not only tribal communities, but the young people who reside in them as well, providing a strong barrier to the gang lifestyle (Grant, 2013).

\section{Conclusion}

A racial stereotype of Indigenous American does not strictly conforms to the reality. The stereotypic image, created by popular culture and spread by Hollywood films all over the world, is distorted by misrepresented facts. The deconstruction of the stereotype is the matter of social equality necessary for Indigenous American to feel and think as members of the world community 
not better or worse than any other. The comparison of stereotypic traits as shown by popular culture and the reality described in the media discourse is given in Table 2.

Table 2.Stereotype vs Reality

\begin{tabular}{|c|c|}
\hline Stereotype & Reality \\
\hline one indigenous nation & $\begin{array}{l}\text { variety of unique cultures and national } \\
\text { identities }\end{array}$ \\
\hline deprived of civil rights & federally recognized sovereign nations \\
\hline totally emerged in indigenous culture & $\begin{array}{c}\text { less than } 30 \% \text { of all Native Americans speak } \\
\text { their tribal language }\end{array}$ \\
\hline on the verge of extinction & $\begin{array}{l}\text { 6, } 7 \text { million Native Americans living in the USA } \\
\text { (the U.S. Census Bureau's survey of November, } \\
\text { 2018) }\end{array}$ \\
\hline reservation residence & 1/3 of Indigenous American live in urban areas \\
\hline humble and helpful & involved in criminal activity \\
\hline impoverished people & business people, Congress members, politicians \\
\hline dressed in feathers and leather & modern outfit with traditional embellishment \\
\hline
\end{tabular}

\section{References}

Acta Lacota Museum Cultural Center. (2019). The "Sioux" Name and Dialects. Retrieved April, 17, 2019, from http://aktalakota.stjo.org/site/PageServer?pagename=alm_culture_origins

Ahton, T. (2018). Native American Gangs. E. Rawson (Ed.) American Subcultures. Boston, New York: Macmillan, 52-61.

Alcalay, G. (1998). Telling Their Own Stories: Native American Stereotypes in Art. Cultural Survival Quarterly Magazine. Retrieved Mae, 17, 2019 from https://www.culturalsurvival.org/publications/cultural-survival-quarterly/telling-their-own-storiesnative-american-stereotypes-art

Allaire, C. (2018). How 6 Indigenous Designers Are Using Fashion to Reclaim Their Culture. Vogue. May, 30, 2018. Retrieved May, 23, 2019 from https://www.vogue.com/article/indigenous-fashion-designerscultural-appropriation-activism

Allport, G. W. (1958). The Nature of Prejudice. Garden City. NY: Doubleday Anchor.

Bartmiński, J. (2016).What does it mean for stereotypes to "reside in language"? Anna Dąbrowska, Walery Pisarek, and Gerhard Stickel (Eds.). Stereotypes and Linguistic Prejudices in Europe. Budapest:

Research Institute for Linguistics Hungarian Academy of Sciences, 115-135. 
Brewer M. B. (2005). Ethnocentrism and Prejudice: A Search for Universals. Crandall, C.S. and Schaller, M. (Eds.) Social Psychology of Prejudice: Historical and Contemporary Issues. Lawrence, KS: Lewinian Press.

Chilton, P. (2004). Analysing Political Discourse: Theory and practice. London, New York: Routledge.

Crow Canyon Archeological Center. (2019). The Origin of the Name "Navajo". Retrieved March, 30, 2019, from https://www.crowcanyon.org/EducationProducts/peoples_mesa_verde/post_pueblo_navajo_name.asp

Eckholm, E. (2009). Gang Violence Grows on an Indian Reservation. The New York Times, December, 13, 2009. Retrieved 25, May 2019, from https:/www.nytimes.com/2009/12/14/us/14gangs.html

Freng, A. (2014). American Indian Gangs. J.I. Ross (Ed.) American Indians at Risk. Vol. I. Santa Barbara, Denver, Oxford: Greenwood, 11-25.

Grant, C. M. (2013). Native American Involvement in the Gang Subculture: Current Trends \& Dynamics. Community Corrections Institute Bureau of Justice Assistance, Office of Justice Programs, U.S. Department of Justice. Retrieved 25, May 2019 from http://www.communitycorrections.org/images/publications/NAInvolveinGangs-Trends.pdf

Hauptman, L. M. (1975). Governor Theodore Roosevelt and the Indians of New York State. Proceedings of the American Philosophical Society. Vol. 119, No. 1, 1-7.

Hudson, N. (1996). From "Nation to "Race": The Origin of Racial Classification in Eighteenth-Century Thought. Eighteenth-Century Studies. Vol. 29, No. 3. The Johns Hopkins University Press, 247-264.

Keiser, A. (1970). The Indian in American Literature. New York: Octagon Press.

Kelly, C. (2019). First Native American Congresswomen Hug after Swearing-in. CNN, January 3, 2019. Retrieved May, 25, 2019, from https://edition.cnn.com/2019/o1/o3/politics/first-native-congresswomenhug/index.html

Kiefer F. (1973). On Presuppositions. Kiefer F., Ruwet N. (Eds) Generative Grammar in Europe. Foundations of Language (Supplementary Series), vol. 13. Springer, Dordrecht, 218-242. DOI https://doi.org/10.1007/978-94-010-2503-4_11

Kilpatrick, J. (1999). Celluloid Indians: Native Americans and Film. Lincoln and London: University of Nebraska Press.

Lubitz R. (2016). The Navajo Nation's Case Against Urban Outfitters Just Took a Hit. Mic, May, 20, 2016. Retrieved Apil, 27, 2019 from https://www.mic.com/articles/143970/the-navajo-nation-s-case-againsturban-outfitters-just-took-a-hit

McLaurin, V. (2019). Why the Myth of the "Savage Indian" Persists. Sapience. February, 27, 2019. Retrieved May, 10, 2019, from https://www.sapiens.org/culture/native-american-stereotypes/

Montgomery, L.M. (2017). Native by Design. Indigenous people in the U.S. are increasingly challenging widespread stereotypes as well as the practice of cultural appropriation. Sapiense, January, 10, 2017. Retrieved May, 1, 2019, from https://www.sapiens.org/culture/native-american-design/

Nagle, R. (2018). Media representation of Native women: invisibility, stereotypes, whitewashing. Women's Media Center. June, 12, 2018. Retrieved March, 27, 2019 from http://www.womensmediacenter.com/news-features/media-representation-of-native-womeninvisibility-stereotypes-whitewashing

Nagle, R. (2018). Research reveals media role in stereotypes about Native Americans. Women's Media Center, July, 18, 2018. Retrieved March, 27, 2019 from http://www.womensmediacenter.com/newsfeatures/research-reveals-media-role-in-stereotypes-about-native-americans 
Native Youth Magazine (2019). Native Americans in Bussiness. May, 2019. Retrieved May, 20, 2019 from http://nativeyouthmagazine.com/business.html

NPR Daily Newsletter. (2012). Navajo Nation Sues Urban Outfitters Over Trademark. Retrieved April, 15, 2019 from https://www.npr.org/2012/04/05/150062611/navajo-nation-sues-urban-outfitters-overtrademark

Reclaiming Native Truth. (2019). A Project to Dispel America's Myths and Missconceptions. Retrieved May, 17, 2019, from https://rnt.firstnations.org/research/

Sarivaara, E., Maatta, K., Uusiautti, S. (2013). Who is indigenous? Definitions of Indigeneity. European Scientific Journal, vol.1, 369-378. DOI: http://dx.doi.org/10.19044/esj.2013.v9n1op\%25p

Stalnaker, R. C. (1974). Pragmatic Presuppositions. M. Munitz and P. Unger, (Eds.) Semantics and Philosophy. New York University Press, 197-230.

van Dijk, T. (1998). Ideology: a Multidisciplinary Approach. London: Thousand Oaks; New Delhi: Sage.

Young, B. (2015). Why I Won't Wear War Paint and Feathers in a Movie Again. Time, June, 11, 2015. Retrieved April, 27, 2019 from http://time.com/391668o/native-american-hollywood-film/

Svitlana Lyubymova, a PhD in German Languages, Associate Professor of the Foreign Languages Department in National Polytechnic University, Odessa, Ukraine. She is the author of 35 academic articles published in Ukraine, Russia, Bulgaria, the USA, India, and Spain. She is currently working on American cultural stereotypes and dominants, their modifications and impact on the world culture. 